DOI: 10.14526/2070-4798-2019-14-2-38-42

\title{
Different physical culture means influence on cognitive and psychomotor indices of medical higher educational establishment students
}

\author{
Elina V. Bulanova*, Vadim G. Osipov, Lubov A. Korshunova, Elvira A Lebedeva \\ Tver State Medical University \\ Tver, Russia \\ ORCID: oooo-ooo3-2336-3835, elina.bulanova@mail.ru* \\ ORCID: oooo-ooo3-1859-1374, osipovtgma@yandex.ru \\ ORCID: 0000-0003-3622-5773, laktv@mail.ru \\ ORCID: 00oo-0003-4023-9772, elya69tv@mail.ru
}

\begin{abstract}
In the opinion of some authors motor activity provides a person's psychicimprovement, his cognitive and psychomotor abilities development. This hypothesis confirmation gives great opportunities for physical culture means use for a person's psychophysiological characteristics development. This problem is especially urgent for students, as on the one hand studying demands high level of attention focusing, good memory, psychomotor endurance; on the other hand, created by teaching process motor activity deficiency can prevent these important for students' qualities development. Materials. The research presents the results of different variants of physical lessons influence on female students' cognitive and psychomotor process indices. Differentiated lessons were held in three groups during 8 months. General number of girls, who took part in the experiment, was 428 people. Research methods. Information sources analysis and summarizing, pedagogical experiment, cognitive and psychomotor indices testing among the girls at the beginning and the end of the academic year, statistical data handling, research results analysis and summarizing. Results. Regular motor activity has a positive influence on cognitive and psychomotor abilities of young people. We revealed the connection between physical culture lessons program and these or that cognitive and psychomotor indices increase. Conclusion. Using different variants of physical culture we can differentially develop students' cognitive and psychomotor abilities.
\end{abstract}

Keywords: students, physical culture lessons, cognitive and psychomotor indices.

For citation: Elina V. Bulanova, Vadim G. Osipov, Lubov A. Korshunova, Elvira A Lebedeva. Different physical culture means influence on cognitive and psychomotor indices of medical higher educational establishment students. The Russian Journal of Physical Education and Sport. 2019; 14(2): 33-37. DOI 10.14526/2070-4798-2019-14-2-38-42.

\section{INTRODUCTION}

In the opinion of some scientists, there is the connection between a person's motor activity and psychic abilities. That is why the interest in students' physical upbringing is conditioned not only by a low level of health and physical readiness among students, but also by the necessity to develop psychomotor and cognitive abilities of young people as the basis of their successful educational and professional activity $[1,3,6,7]$.

At the same time, high cognitive indices, psychomotor endurance, sensory working capacity, coordination of free motor actions are important for professional success and competitiveness in many professions. Good functional abilities of central nervous system (CNS) are necessary for a successful professionally important qualities formation among the future specialists. That is why the importance of their improvement is obvious and even economically expedient $[2,4,5,6,8]$.

The aim of the research is to create different variants of physical culture lessons and estimate their influence on cognitive and psychomotor indices of CNS functioning among female students.

The objectives of the research:

1. To define the values of cognitive and psychomotor CNS indices among girls at the beginning of the academic year.

2. To create several variants of physical culturehealth improving lessons, directed toward cognitive and psychomotor CNS indices development.

3. To define the influence of different variants 
of physical culture health improving lessons on cognitive and psychomotor CNS indices.

\section{MATERIALS AND METHODS}

428 female students of the 1st and the 2nd courses took part in the experiment (Tver State Medical University). Three groups were formed: the 1st group - 257 people, the 2nd group - 53 people, the 3 rd group - 118 people. The lessons in the experimental groups were held according to different programs during the whole academic year. The influence of different variants of physical culture lessons on cognitive and psychomotor indices was estimated according to the results of testing at the beginning and the end of the academic year.

The object of the research: cognitive indices (memory, attention, logical thinking); psychomotor indices (visual-motor reaction, psychomotor reaction, endurance, speed of movements).

\section{RESEARCH METHODS:}

1. Tapping-test, during which we estimated the following: the average speed of hand movements (ASHM); maximal speed of hand movements (MSHM); quickness of reaction (QR); quickness of movements (QM); speed endurance (SE).

2. Visual-motor reaction test (VMR), which is held with the help of ruler, was estimated in centimeters and according to 5-point system.

3. Operative memory (OM) test, held with the help of the tables. They contain 12 double figures. The number of the remembered figures was estimated.

4. Attention test was held with the help of Schulte tables (AS). They help to estimate the speed of attention redirection and focus. The time, spent for the test (sec.) and also the mistakes during figures search was estimated. It was demonstrated in a form of 5-point scale.

5. Attention test during the work with the text, held according to Munsterberg methodology (AM). The time, spent for the test, the number of mistakes (AMM) during the work with the text was estimated; point estimation was realized according to Munsterberg criteria.

6. Lippman logical thinking test (LM). We estimated the time, which was spent for the test, the number of made mistakes (LMM); point estimation was realized according to Lippman criteria.

The peculiarities of physical culture lessons in the formed groups:

1. The female students of the 1st group trained according to the traditional physical culture program for higher educational establishments.

2. Into the 2nd group lessons we included special blocks of physical exercises:

- the elements of rhythmic gymnastics; the exercises, directed toward static muscles endurance increase; relaxation stretching $[9,10]$;

- hands and legs cross movements, directed toward the functions of two hemispheres integration;

- $\quad$ visual-motor cross movements;

- $\quad$ problem task reproduction during its single announcing.

3. The lessons of the 3 rd group included the following special exercises:

- different variants of cross movements, produced by hands and legs;

- problem tasks concerning motor actions analysis, synthesis and summarizing;

- $\quad$ relaxation stretching $[10,11]$.

\section{RESULTS AND DISCUSSION}

During the dynamics of cognitive and psychomotor indices comparison in the experimental groups in terms of different variants of physical culture lessons the following things were revealed (table):

valid psychomotor indices improvement in the 1st and the 2nd groups (ASHM, MSHM, QR, QM), validly higher increase was in the 2nd experimental group; in the 3 rd group all these indices became validly lower;

- the index of visual-motor reaction considerably improved in all groups (without valid differences between the groups);

- $\quad$ theindex of speed enduranceincreased in the 2nd and the 3rd groups. However, its considerable increase in the 3 rd group can be connected with the fact, that these students had considerable hand movements decrease. That is why preference should be given to considerable speed endurance index dynamics among female students of the 2nd group;

- $\quad$ female students of all groups had operative memory improvement (without valid differences 
between the groups), however, this index increase in the 2nd group was lower, than in the 1st and the 3rd groups;

- $\quad$ attention testing during the work with the text showed that considerable mistakes decrease to the end of the academic year was in the 2nd group, in the 1st group the result turned out to be worse. In the 3 rd group general result of this test turned out to be better only because female students fulfilled the test quicker, but made a lot of mistakes. It makes this result unfavorable;

- $\quad$ female students from the 3 rd group showed validly better results of logical thinking testing: their time, spent for the task fulfillment, decreased considerably as well as the number of made logical mistakes; in the 1st group insignificant dynamics was in the number of mistakes, in the 2nd group the time of test decreases, but the number of logical mistakes increased.

Table 1 - The results of testing female students from the experimental groups at the beginning and the end of the academic year

\begin{tabular}{|c|c|c|c|c|c|c|}
\hline \multirow{3}{*}{ Index } & \multicolumn{6}{|c|}{ Experimental groups } \\
\hline & \multicolumn{2}{|c|}{ The 1st group } & \multicolumn{2}{|c|}{ The 2nd group } & \multicolumn{2}{|c|}{ The 3rd group } \\
\hline & initial & final & initial & final & initial & final \\
\hline ASHM & $61,8 \pm 1,1$ & $66,2 \pm 0,6^{* * *}$ & $62,4 \pm 1,0$ & $73,0 \pm 2,2^{* * *}$ & $60,8 \pm 1,0$ & $58,5 \pm 0,7$ \\
\hline MSHM & $70,7 \pm 1,4$ & $76,3 \pm 0,8^{* * *}$ & $70,8 \pm 1,4$ & $82,0 \pm 2,3^{* * *}$ & $70,2 \pm 1,2$ & $65,3 \pm 1,0^{* *}$ \\
\hline QR & $4,7 \pm 0,03$ & $4,8 \pm 0,03^{*}$ & $4,7 \pm 0,1$ & $4,9 \pm 0,08$ & $4,8 \pm 0,07$ & $4,0 \pm 0,1^{* * *}$ \\
\hline QM & $4,5 \pm 0,03$ & $4,7 \pm 0,02^{\star * *}$ & $4,5 \pm 0,04$ & $4,9 \pm 0,04^{* * *}$ & $4,4 \pm 0,07$ & $4,2 \pm 0,07^{\star}$ \\
\hline SE & $2,6 \pm 0,06$ & $2,7 \pm 0,2$ & $2,3 \pm 0,2$ & $2,9 \pm 0,2^{*}$ & $2,2 \pm 0,2$ & $3,6 \pm 0,1^{* * *}$ \\
\hline $\operatorname{VMR}(\mathrm{cm})$ & $21,4 \pm 0,3$ & $16,6 \pm 0,3^{* * *}$ & $19,7 \pm 0,8$ & $15,5 \pm 0,7^{\star * *}$ & $19,6 \pm 0,7$ & $16,8 \pm 0,5^{\star *}$ \\
\hline VMR(point) & $2,8 \pm 0,05$ & $3,9 \pm 0,05^{* * *}$ & $3,2 \pm 0,2$ & $4,1 \pm 0,1^{\star * *}$ & $3,3 \pm 0,1$ & $3,9 \pm 0,1^{* * *}$ \\
\hline $\mathrm{OM}$ & $6,9 \pm 0,1$ & $7,8 \pm 0,1^{* * *}$ & $5,3 \pm 0,4$ & $8,1 \pm 0,3^{\star * *}$ & $5,7 \pm 0,3$ & $7,4 \pm 0,3^{* * *}$ \\
\hline AS (sec.) & $151,1 \pm 2,0$ & $139,6 \pm 2,3^{\star * *}$ & $155,7 \pm 6,9$ & $148,2 \pm 10,0$ & $157,7 \pm 4,5$ & $144,8 \pm 4,1^{\star}$ \\
\hline AS(point) & $3,0 \pm 0,02$ & $3,2 \pm 0,02^{* * *}$ & $3,0 \pm 0,08$ & $3,0 \pm 0,08$ & $2,8 \pm 0,07$ & $3,1 \pm 0,07^{\star *}$ \\
\hline $\mathrm{AM}$ (sec.) & $139,9 \pm 5,5$ & $157,7 \pm 3,7^{\star *}$ & $152,7 \pm 8,4$ & $171,4 \pm 9,0$ & $156,8 \pm 8,1$ & $139,4 \pm 8,7$ \\
\hline AM (point) & $9,6 \pm 0,3$ & $7,8 \pm 0,3^{* * *}$ & $8,2 \pm 0,8$ & $7,0 \pm 0,8$ & $7,3 \pm 0,8$ & $8,8 \pm 0,7$ \\
\hline AMM & $2,2 \pm 0,2$ & $2,1 \pm 0,1$ & $2,0 \pm 0,3$ & $1,5 \pm 0,3$ & $2,7 \pm 0,3$ & $2,9 \pm 0,2$ \\
\hline LM (sec.) & $274,0 \pm 7,7$ & $270,8 \pm 6,4$ & $331,7 \pm 27,2$ & $309,0 \pm 17,9$ & $267,5 \pm 12,7$ & $228,5 \pm 7,4^{* *}$ \\
\hline LM (point) & $3,8 \pm 0,3$ & $3,8 \pm 0,3$ & $3,9 \pm 0,5$ & $3,9 \pm 0,6$ & $5,0 \pm 0,4$ & $6,1 \pm 0,4^{*}$ \\
\hline LMM & $4,4 \pm 0,2$ & $4,3 \pm 0,3$ & $3,6 \pm 0,4$ & $3,8 \pm 0,5$ & $3,2 \pm 0,3$ & $2,5 \pm 0,4$ \\
\hline
\end{tabular}

\section{CONCLUSION}

During the held research we managed to reveal that the offered variants of physical culturehealth improving lessons have different influence on cognititve and psychomotor indices of CNS functioning.

Physical culture lessons, organized in a traditional way (the 1st group), considerably improve psychomotor indices. However, we didn't reveal any positive dynamics of cognitive indices.

The important psychomotor index for student's educational activity and medical work is speed endurance. This psychomotor index improvement was only among the female students from the 2nd group. It can be explained by using the elements of rhythmic gymnastics during physical culture-health improving lessons.

If we include "Problem task reproduction during its single announcing" block in to the lesson, it provides attention and operative memory increase. Block "Problem tasks according to motor actions analysis, synthesis and summarizing" provides logical thinking improvement.

Thus, using different variants of physical culture 
lessons we can differentially develop students' cognitive and psychomotor abilities.

\section{REFERENCES}

1. Bulanova E.V., Makarov V.M. The basis of professionally-applied physical training of medical University students. Teoreticheskie I prakticheskie voprosy razvitiya nauchnoy mysli v sovremennom mire: sbornik statej II Mezhdunarodnoj nauchnoprakticheskoj konferencii. 29-30 aprelya 2013g.: v 4-h chastyah [Theoretical and practical issues of scientific thought development in the modern world : the collection of scientific articles of the II International scientific-practical conference. April, 29-30, 2013: in 4 parts]. Ufa: RITS Bashkiriya State University. 2013; 3: 322.

2. Zheleznyak Y.D., Leifa A.V. Physical activity and students' health at non-physical culture higher educational establishment. Teoriya i praktika fizicheskoi kultury i sporta $=$ Theory and practice of physical culture. 2006; 12: 46-47 (In Russ., In Engl.).

3. Osipov V.G. Physical culture as the element of a healthy life style and professional training of medical students. Metodologiya formirovaniya zdorovogo obraza zhizni: medicopeadagogicheskie aspekty: materialy regional'noj nauchno-prakticheskoj konferencii [Methodology of a healthy lifestyle formation: medico-pedagogical aspects: materials of the regional scientific-practical conference]. Tver: RITS TSMA. 2012: 115-119.

4. Semenova E.A. The peculiarities and dynamics of professional self- conscience of students. Psikhopedagogika v pravookhranitelnykh organakh. 2012; 3(50): 25-28 (In Russ.).

5. Daskapan A., Tuzun E.H., Eker L. Relationship between physical activity level and health related quality of life among university students. Saudi Medical Journal. 2005; 26: 10261028.
6. Extremera N., Fernandez-Berrocal P. Emotional intelligence as predictor of mental, social and physical health in university students. Spanish Journal of Psychology. 2006; 9(1): 45-51.

7. Ghaedi G.H., Tavoli A., Bakhtiari M., Melyani M., Sahagard M. Quality of life in college students with and without social phobia. Social Indicators Research. 2010; 97: 247-256. DOI: 10.1007/s11205-009-9500-3.

8. Li G.S., Lu F.J.H., Wang A.H. Exploring the relationships of physical activity, emotional intelligence and health in Taiwan college students. Journal of Exercise Science and Fitness. 2009; 7(1): 55-63. DOI: 10.1016/S1728-869X(o9)60oo8-3.

9. Mikolajcsyk R.T., Brzoska P., Maier C., Ottova V., Meier S., Dudziak U., ..., El Ansari W. Factors associated with self-rated health status in university students: A cross-sectional study in three European countries. BMC Public Health. 2008; 8: 215. DOI: $10.1186 / 1471-2458-8-215$.

10. Svetlana A. Fazleeva, Valeriy D. Panachev. Physical Culture as The Method of Education Quality Improvement. Pedagogiko-psihologicheskie I medico-biologicheskie problemy fizicheskoj kul'tury I sport = Pedagogico-psycological and medicobiological problems of physical culture and sports. 2016; 11(4): 103-108. DOI: 10.14526/01_1111_162 (In Russ., In Engl.).

11. Leonid A. Zelenin, Alexsandr N. Legotkin. Scientific-theoretical basis of gaining knowledge using training simulators at physical culture lessons. Pedagogiko-psihologicheskie I medicobiologicheskie problemy fizicheskoj kul'tury I sport $=$ Pedagogico-psycological and medico-biological problems of physical culture and sports. 2016; 11(4): 36-40. DOI: 10.14526/01_2017_182 (In Russ., In Engl.).

Submitted: 19.04.2019

\section{Author's information:}

Elina V. Bulanova - Senior Lecturer, Tver State Medical University, 17oooo, Russia, Tver, Sovetskaya str., House 4, e-mail: elina.bulanova@mail.ru 
Vadim G. Osipov - Candidate of Medical Sciences, Professor, Tver State Medical University, 17oooo, Russia, Tver, Sovetskaya str., House 4, e-mail: osipovtgma@yandex.ru

Lubov A. Korshunova - Senior Lecturer, Tver State Medical University, 170ooo, Russia, Tver, Sovetskaya str., House 4, e-mail: laktv@mail.ru

Elvira A. Lebedeva - Assistant, Tver State Medical University, 170ooo, Russia, Tver, Sovetskaya str., House 4, e-mail: elya69tv@mail.ru 